\title{
Rockefeller Foundation's Typhoid Control Campaign at Kalutara- Totamune in Sri Lanka
}

\author{
Soma Hewa \\ School of Policy Studies, Queen's University, Kingston, Ontario, Canada \\ Correspondence: 69, Ross Street, Chateauguay, Quebec,J6J2B1, Canada. (somawantha@sympatico.ca)
}

\begin{abstract}
The Kalutara Health Unit, established in 1926 by the International Health Board (IHB) of the Rockefeller Foundation, functioned as a "model" of public health in Asia. Typhoid fever endemic in the Kalutara health unit area during the 1930s caused concern for the IHB representative in Sri Lanka because the health unit served as the training center for the local and foreign public health personnel. After a number of unsuccessful attempts to control the disease, the IHB sponsored a bacteriological analysis of the problem, followed by a two-year sanitary engineering project that brought the disease under control. The successful typhoid control program in the Kalutara health unit area was an excellent case of international cooperation, and local community support in disease control that contributed to Sri Lanka's outstanding health achievements.
\end{abstract}

\section{Key Words: Kalutara Health Unit, Typhoid fever, Rockefeller Foundation}

\section{Introduction}

“As early as 1915, Ceylon was regarded as the key to the situation in the East, particularly for work in British colonies. ... Since then Dr. Jacocks has continued to serve as adviser to the Director of Medical and Sanitary Services, and supervised the creation of the divisions of sanitary engineering and public health education, and persuaded Government to establish the system of health units which has been such an important factor in the development of similar units in other eastern countries"(1).

The above paragraph sums up the importance of Sri Lanka, then known as Ceylon, for the public health campaign of the International Health Board (IHB) of the Rockefeller Foundation in the East. Although the IHB's involvement in Sri Lanka began with a hookworm control campaign among the Indian immigrant workers on the plantations in 1915, the landmark sanitary engineering and health education program, known as the "health unit system," began in 1926 when the first such unit in Asia was established at Kalutara, Totamune (2), a suburb about $43 \mathrm{~km}$ south of Colombo. Speaking at the opening ceremony, Dr. W.P. Jacocks of the IHB stated: "July $1^{\text {st }} 1926$, will be remembered by Health
Workers in Ceylon as the day on which a real step forward was taken in rural health work along modern lines"(3).

The purpose of this paper is to examine the role of the IHB in controlling typhoid in the Kalutara health unit area during the 1930 s, when the disease had become endemic in several communities. The IHB together with the Kalutara health unit developed a detailed plan and recruited a bacteriologist to study the problem. Following the study, the IHB along with the government of Sri Lanka undertook a major sanitary engineering project to provide proper latrines and clean water for the people of the Kalutara health unit area in order to bring the typhoid disease under control.

\section{Typhoid in Kalutara Health Unit Area}

Typhoid fever, also known as enteric fever, is still one of the major diseases associated with the poor sanitary conditions in the developing world. According to World Health Organization, about 17 million people become infected each year by typhoid worldwide, and roughly a quarter of a million die from the disease. The disease is caused by contamination of food, milk or water with 
Salmonella typhi bacteria, directly by sewage, indirectly by flies or by poor personal hygiene. The symptomless carriers harboring bacteria in the gallbladder and excreting in stools are the main source of outbreak of disease. The average incubation period ranges from 10 to 14 days, and a progressive fever that marks the onset develops gradually as the microbe invade lymphoid tissue and the small intestine causing profuse diarrhea, which may become hemorrhagic. The recovery usually begins by end of the third week (4).

Amongst numerous infectious diseases, typhoid was a major public health problem in the early $20^{\text {th }}$ century Sri Lanka. A report on the first six months (from July to December, 1926) of the Kalutara health unit prepared by the senior medical officer, Dr. S.F. Chellappah, pointed out that "typhoid fever, like dysentery, is endemic in the area; 15 cases were notified, 4 in the rural and 11 in the urban areas, and 6 cases proved fatal." He further noted that although the actual number of deaths due to typhoid was 9 , only 6 had been reported. In the following years, the senior medical officer of the health unit continued to report a large number of typhoid cases with a rising death toll. By 1929, the number of typhoid cases reported had risen to 132 with 25 deaths. During that year, typhoid was an endemic in several communities in the health unit area, and occasionally an epidemic; one such "epidemic occurred at Pinhena, a little village five miles North-East of Aluthgama." The medical officer again emphasized the difficulty of getting accurate typhoid morbidity and mortality figures: "The reporting of cases is yet not satisfactory as might be expected... At present it would be fair to say that only about 25 percent of the cases are being reported." The recurring typhoid puzzled the senior medical officer, who attributed the source of infection to a polluted well (5). However, the attempt to deal with the problem remained haphazard.

In 1930, the director of medical and sanitary services, Dr. R. Briercliffe resolved to undertake an experimental bored-hole latrine project for about 200 to 300 families in villages to demonstrate the importance of sanitation for the prevention of disease, particularly typhoid. In writing to the IHB representative, Dr. Briercliffe argued: "I am of the opinion that the work would receive a definite stimulus and obtain greater support from the public and from government if a demonstration could be arranged to show the value of sanitation completely in a selected village with latrines of a suitable type." For this purpose, Dr. Briercliffe requested a grant of $\$ 2000$ from the IHB, as the government itself was unable to bear the cost given the depressed financial situation in the country (6).

The project was approved, and was implemented under the supervision of Dr. Jacocks, the IHB representative in Sri Lanka. Following the successful completion of the project, all the equipment bought by the IHB worth over Rs. 460/was donated to the department of medical and sanitary services to carry out further work. In addition, Dr. Jacocks recommended to the IHB that another Rs. 5,000/- grant be made "for bored-hole latrines in Ceylon and that these latrines be installed so far as possible in health unit areas." This too was approved by the IHB, and the grant was utilized to produce hundreds of squatting plates for bored-hole latrines. These squatting plates were in turn sold to people at a nominal price (about Rs. 4/- each) through various village committees and cooperative societies to be paid in several installments. In writing to the Rockefeller Foundation about the progress of the project, Dr. Jacocks stated: "the bored-hole latrines continue to be popular and satisfactory and are receiving favorable comment from responsible people, including the members of the State Council"'(7). The latrine construction continued for a few more years, and over one thousand new boredhole latrines were built in several villages. In addition, hundreds of "mould" latrines were built by using empty steel tar barrels as pit lining at a cost of Rs. 3/-, including the squatting plate. Writing on the ongoing latrines construction project Dr. Jacocks stated, "The great increase in this work is most encouraging... In general the latrines were used, and soil pollution was not noticeable"(8). Nonetheless, despite the fact that a large number of latrines were constructed in the Kalutara health unit area, typhoid fever continued to be a major public health threat in the area.

Given the importance of the Kalutara health unit as the training center for local and international public health personnel, Dr. Jacocks felt the urgency of controlling the recurring typhoid disease in the nearby communities. In 1933, for example, as part of the IHB's campaign to expand the health unit concept in Asia, a group of 18 medical officers of health and public health nurses from India, Burma, and Java was invited to Kalutara for up to six months training on disease control and health education. He wrote, 
"Kalutara has been, and continues to be, the chief training center for the East. Without the facilities, which it offers our rural work would be immeasurably handicapped...Good work has already been done and reported on typhoid fever" (9). Hence, the IHB representative in Sri Lanka was keen to "showcase" the achievements of the Kalutara health unit to those visiting public health personnel. For all these reasons, Dr. Jacocks decided to find the source of the recurring typhoid in the Kalutara health unit area and to initiate a systematic bacteriological investigation into the problem. He wrote to the IHB requesting an annual grant of Rs. 6,000/- to recruit a medical officer of health trained in bacteriology for a period of 2 years. He argued that this person was to carryout a thorough bacteriological testing of fecal specimens from suspected persons within the health unit area, and the final analysis was to be done at the Colombo Bacteriological Institute, so that a clear picture of the problem can be attained: "In view of the high incidence of enteric fever from year to year in the Kalutara district and other districts in Ceylon," wrote Dr. Jacocks, "the study is an important one and should be pursued" (10).

The program was approved by the IHB, and Dr E. J. Ratnayake, a bacteriologist, was recruited to carry out the investigation. Following the investigation, it became clear that the southern sector of the Kalutara health unit, which included Maggona East, Maggona West, Diyalagoda and Magalkande were typhoid endemic, and all four villages had a long history of typhoid with an increasing number of cases each year since 1931. For example, in 1937 the four villages reported 59 typhoid cases with 14 deaths. The report pointed out that "The sanitary conditions of the area are far from satisfactory. It is thickly populated and there is much over-crowding. A large proportion of the houses at Maggona West, East and Diyalagoda are without latrine accommodation and most of the existing ones are pit latrines. The water supply is from unprotected wells. The wells are owned by private individuals but for generations they have been used as communal wells." The poor sanitary conditions were further aggravated by the particular terrain of the area, being low-lying and sandy with high subsoil water.

It became clear that the problem of typhoid in these communities could not be solved without addressing the problem of proper latrines and drinking water supply systems in the area. The latrines had to be

Galle Medical Journal, Vol 16: No. 1, March 2011 designed and installed according to the specifications of the sanitary engineering division of the public health department to fit the particular soil conditions, and the wells had to be fully covered and sealed. The bathing and washing platforms needed to be constructed away from the wells with properly built drainage. It was estimated that 1106 households in those four communities had to be provided with appropriate type of latrines, and about 50 or so community-wells in the area needed to be fitted with pumps to provide drinking water to solve the typhoid problem(11).

\section{Financing the Project}

Although Dr. Jacocks moved to India in 1934 as the IHB representative, he continued to advice on health unit work in Sri Lanka on behalf of the IHB. He was keen on completing the sanitary project, as it would immensely improve the health of the people in those communities. Without the sanitary work, Dr. Jacocks argued, all the efforts to improve public health at the Kalutara health unit area would be futile. The plans were drawn up by Dr. Jacocks together with the department of sanitary services, and a budget was prepared. The project was to be completed in two years. It was estimated that the cost of installing latrines was Rs. 13,000/-, and the pumps and accessories for the wells would cost Rs. 12,000/-. Of the total cost (Rs. 25,000/-) of the project, the IHB was to contribute Rs. 10,000/-. In recommending the plan to the scientific directors of the IHB, Dr Jacocks wrote: "Ceylon has been foremost in developing rural health work and is going forward steadily...The present work is to be located in one of the remote parts of the Kalutara health unit, which has received less attention heretofore. The Kalutara health unit is still used by India for training medical officers of health in health unit principles. The provision of latrines and the installation of pumps are important items for the trainees to study" (12).

The proposal was approved by the IHB in December 1939, and the first installment of Rs. 5000 for 1940 was made. The health unit itself organized the local people into several voluntary groups, such as the Social Service League and Health League to assist the work (13). The work progressed smoothly despite a slight delay of acquiring the necessary equipment and material due to the World War II. The construction of latrines and community-wells were supervised by the department of public health, and 
the entire project was completed by the end of 1942 , within the stipulated two-year period.

Following the extensive sanitary engineering work, there was a dramatic drop in the number of typhoid cases in the Kalutara health unit area. However, the outbreak of cholera and smallpox on the island during the early 1940s required a sustained effort on the part of the authorities to improve public health throughout the country. The IHB, for its part, continued to play a role in public health and training of health care personnel in Sri Lanka until the late 1950s.

\section{Conclusion}

With the establishment of the first health unit at Kalutara in 1926, the curative and preventive services were unified under one administration. In 1927, the IHB provided the services of a sanitary engineer who organized a division of sanitary engineering, which made an immense contribution to the work of the health units. It undertook, among other things, to experiment with suitable latrines, not only for the Kalutara health unit, but also for the other health units in the country. All these public health measures that controlled infectious diseases during the early part of the twentieth century laid a solid foundation for the development of long-term preventive and curative health services in the country (14). While the Kalutara health unit was developed as a model of public health; its facilities were utilized to train public health personnel to expand the health unit concept in Sri Lanka, as well as in other countries in Asia. It not only symbolized the successful cooperation between the national health authorities and an international organization to achieve specific health objectives, but it also laid the foundation for the development of a network of health services that resulted in an outstanding record in life expectancy and mortality rates in Sri Lanka comparable to those of industrialized developed countries.

\section{References}

1. Rockefeller Archive Center (hereafter RAC), Rockefeller Foundation Report on Asia (Ceylon), 1925 Record Group (RG.) 5, Series (Se.) 2, Box 2, p. 13. The International Health Board (IHB) became the International Health Division (IHD) in 1928, which ceased to exist in 1953. However, for the purpose of consistency I refer to the IHB as the Rockefeller Foundation's public health campaign throughout this paper.

2. The area that the health unit was initially expected to serve was about 40 square $\mathrm{km}$. with a population of approximately 30,000. This included 1 urban center, 27 villages, and 7 large rubber plantations. It was believed that the selected area represented the island's population and their health problems at the time.

3. RAC, First Annual Report of the Health Unit Kalutara Badda, 1926, RG. 5, Se. 3, Box 198, p. 1.

4. World Health Organization, Water Sanitation Health, Water-Related Disease: Typhoid and paratyphoid enteric fevers, Geneva, 2010.

5. RAC, The Annual Report of the Lower Division of the Kalutara Health Unit for 1928, by Dr H. A. Direckze, March 1929, RG 5, Se. 3, Box 198, pp. 18-19.

6. RAC, A letter regarding the sanitation of a village from $D r$. $R$ Briercliffe, Director of Medical and Sanitary Services to Dr W. P. Jacocks, Representative in Ceylon of the International Health Board of the Rockefeller Foundation, Torrington Square, Colombo, 6th October, 1930, RG. 1.1, Se. 462 Ceylon, Box 1, pp. 1-3.

7. RAC, A letter from Dr Jacocks to Dr Victor G. Heiser, September 28, 1932, RG. 1.1, Se. 462, Box 1, p. 1.

8. RAC, Excerpt from report attached to letter of October 29, 1934 by Dr W. P. Jacocks to Dr Russell, Kalutara with Drs Chellappah and Das Gupta Discussed, 1934, RG. 1.1, Se. 462, Box 1.

9. RAC, Ceylon, Kalutara Health Unit, W. P. Jacocks, 1935, RG. 1.1, Se. 462, Box 1, p. 1.

10. RAC, Excerpt from report attached to letter of October 29, 1934 by Dr W. P. Jacocks to Dr Russell, Kalutara with Dr Briercliffe Discussed, 1934, RG. 1.1, Se. 462, Box 1.

11. RAC, Ceylon-Control of Soil-Born Disease, New Project, Division of Sanitary Engineering, 1940, RG. 1.1, Se. 462, Box 1, pp. 39235-39236.

12. RAC, Ceylon, Kalutara Health Unit Control of Soil Born Diseases, 1939, RG. 1.1, Se. 462, Box. 1, pp. 1-3.

13. RAC, Kalutara Health Unit, Ceylon, 1933, RG. 1.1, Se. 462, Box 1. p. 1.

14. World Health Organization, Report of the Commission on Social Determinants of Health, Closing the gap in a generation: Health equity through action on the social determinants of health, Geneva, 2008, pp. 33, 113, 138, 195. 